\title{
AVAILABILITY OF DURESS AND FRAUD UPON THE PRINCIPAI AS DEFENSES TO THE SURETY AND GUARANTOR
}

\author{
EARL C. ARNold
}

To enter into contractual relations, the minds of the parties must be free to act. Elementary requirements would prevent any binding effect to be given to an agreement made as a result of compulsion or deception by the one seeking to benefit by it. On these general propositions courts are in accord. Adjudications arising out of their application to individual cases are not always easy to reconcile. What constitutes duress? In the case of fraud by one party to a contract, do courts follow the same rules as would be applied if duress had been imposed? Is duress or fraud by a stranger available to the obligor? How do fraud and duress as defenses differ if pleaded by a party to a negotiable or non-negotiable instrument? May the surety or guarantor, on whom was exercised no force or deception, avail himself of the defense that the obligee imposed duress or fraud upon the principal? If the guarantor sets up such a defense, is it material that he is a conditional or absolute guarantor? Is there any difference if the obligation is a criminal bail bond rather than a civil bond?

\section{What Is DuRESS?}

It is obvious that the will may be overcome by sympathy, propaganda, appeal to vanity, false statement, threat to person, property or family. Certainly successful appeals to sympathy or vanity, or a contract induced as the result of propaganda, will afford no defense, for the reason that while these may motivate one to enter into contractual relations, the obligor's will has free choice to act. It is likewise apparent that the influence or fraud which will overpower one person may have no effect upon another. We are not all created equal in powers of resistance. While the common law and the older cases in this country applied 
the nebulous formula that in order to vitiate a contract fraud or duress must be such as would overpower a courageous man, or one of ordinary firmness, ${ }^{1}$ the more modern view is that "susceptibility to coercive influence is not uniform, and, in determining the question of duress, sex, age, state of health, family conditions, etc., may be considered with the other circumstances." 2 The tendency of the modern opinions is to discard the "arbitrary yardstick" made to measure persons "of ordinary intellect, firmness, and courage," $"$ and determine whether in each case the mind of the contracting party was overcome. ${ }^{4}$

${ }^{1}$ The United States Supreme Court approved this rule in U. S. v. Huckabee, I6 Wall. 4I4, 432 (U. S. 1873): "Unlawful duress is a good defense to a contract if it includes such degree of constraint or danger, either actually inflicted or threatened and impending, as is sufficient in severity or apprehension to overcome the mind and will of a person of ordinary firmness." Accord: Pierce v. Brown, 7 Wall. 205, 214 (U. S. 1868); French v. Shoemaker, I4 Wall. $3 \mathrm{I} 4$ (U. S. $187 \mathrm{I}$ ) ; Lafayette \& Indianapolis R. R. v. Pattison, $4 \mathrm{I}$ Ind. 312, 320 (1872); Beeching, Recovery of Money Paid under Duress of Legal Proceedings in Michigan (I9I7) I5 MICE. L. REv. 228, 229; PAGE, CoNTRACTS (I920) \$\$ 437, 482; WOODWARD, QUASI-CONTRACTS (I9I3) \$212.

${ }^{2}$ International Harvester Co. v. Voboril, 187 Fed. 973,974 (C. C. A. 8th, I9II), approved in Meyer v. Guardian Trust Co., 296 Fed. 789 (C. C. A. 8th, I924), and Guardian Trust Co. v. Meyer, I9 F. (2d) I86 (C. C. A. 8th, ID27). Accord: Hartford Insurance Co. v. Kirkpatrick, III Ala. 456, 20 So. 651 (1806); Wilbur v. Blanchard, 22 Idaho 517, 126 Pac. I069 (I912); Baldwin v. Hutchinson, 8 Ind. App. 454, 35 N. E. 7 I I (I893) ; Parmentier v. Pater, 13 Ore. I2I, 9 Pac. 59 (I885) ; Note (I920) zo CoL L. REv. 80; Note (I9r4) I VA. L. REv. 481, 483; (Ig2I) 30 YALE L. J. 760-76r. The Supreme Court of Wisconsin said in Galusha v. Sherman, Io5 Wis. $263,278,8 \mathrm{I}$ N. W. 495,500 (1899): "The question in each case is, Was the alleged injured person, by being put in fear by the other party to the transaction for the purpose of obtaining an advantage over him, eeprived of the free exercise of his will power, and was such advantage thereby obtained? If the proposition be determined in the affirmative, no matter what the nature of the threatened injury to such person, or his property, or the person or liberty of his wife or child, the advantage thereby obtained cannot be retained. . . The means used to produce that condition, the age, sex and mental characteristics of the alleged injured party, are all evidentiary, merely, of the ultimate fact in issue, of whether such person was bereft of the free exercise of his will power. Obviously, what will accomplish such result cannot justly be tested by any other standard than that of the particular person acted upon. His resisting power, under all the circumstances of the situation, not any arbitrary standard, is to be considered in determining whether there was duress." See Anson, ConTRACrS (I6th ed. 1923) 220 (American ed. I924) § 228, ed. n. 4.

${ }^{8}$ Nebraska Mutual Bond Ass'n. v. Klee, 70 Neb. 383, 387, 97 N. W. 476, 478 (1903). Accord: Riney v. Doll, II6 Kans. 26, 30, 225 Pac. I059, 106I (1924). For discussion of statutory definitions of duress, see Merchants' Collection Agency v. Roantree, 37 Cal. App. 88, 173 Pac. 600 (I918) ; Pendleton v. Greever, 80 Okla. 35, 193 Pac. 885 (I920).

"Nor, is it, in my opinion, the true policy of the law to make an arbitrary and unyielding rule in such cases to apply to all alike, without regard to age, sex, or condition of mind. Weak and cowardly people and old and ignorant persons are the ones that need the protecticn of the courts, and they 
The means of duress employed differ according to the degeneracy or needs of the one resorting to its use. Physical force is admittedly duress, as is a threat to resort immediately to physical power to compel one to sign an instrument. ${ }^{5}$ But moral compulsion may be equally as effective as a means to accomplish duress as threats of personal violence. ${ }^{6}$ Duress may therefore consist of imprisonment which deprives one of his liberty, ${ }^{7}$ or it may be per minas, of which Coke mentioned four kinds, fear of loss of life, of loss of member, of mayhem, of imprisonment. ${ }^{8}$

Imprisonment may, of course, be justified or not; it may be with or without legal process. In an opinion written over a century ago, duress by imprisonment was rather euphoniously described to exist "when there is an arrest for improper purposes, without a just cause; or where there is an arrest for a just cause, but without lawful authority; or where there is an arrest for a just cause, and under lawful authority, for unlawful purposes." o

A promise to make restitution, induced by threats of prosecution for a violation of the criminal law, is not necessarily duress so long as the promise did not involve compounding an offense. The duty resting upon all who know of the commission of a crime to assist in bringing the offender to justice would make absurd a rule which would permit the offender to recover money paid after

are the ones usually operated upon and influenced by threats and menaces." Cribbs v. Sowle, 87 Mich. $340,347,49$ N. W. 587,589 (189I). Accord: Coffelt v. Wise, 62 Ind. 451, 454 (1878) ; Williamson-Halsell Frazier Co. v. Ackerman, 77 Kan. 502, 94 Pac. 807 (I908); Anthony \& Cowell Co. v. Brown, 2I4 Mass. 439, Ior N. E. I056 (I913) ; Phillips, $A$ Consideration of What Amounts to Duress Per Minas at Law (1875) 23 AM. L. REg. 20I; (19I8) 2 Minn.

L. REv. 463,464

${ }^{\circ}$ Owens v. Mynatt, I Heisk. 675 (Tenn. I870).

- "Coercion may be accomplished by a set of circumstances brought about by designing persons as effectually and as wrongfully as it may be accomplished by direct threats and menace." Cochrane v. Nelson, 45 S. D. 609, 615, I89 N. W. 700,702 (I922).

"See (I923) 23 CoL. L. REv. 7I.

${ }_{2} 2$ COKE, INST. 483; 3 BACON's ABR. 252; I BL. CoMM. *I30-I3I; 2 GREENLEAF, EVIDENCE (I6th ed. I899) \$\$ 30I-302; 3 WHIISTON, CoNTrACTS (I920) § I60r; Pierce v. Brown, 7 Wall. 205, 215 (U. S. I868); Baker v. Morton, I2 Wall. I50, I58 (U. S. I870) ; Morse v. Woodworth, I55 Mass. 233, 250,29 N. E. 525,528 (I892).

- Richardson v. Duncan, 3 N. H. 508, 51 II (I826). Accord: Baker v. Morton, supra note 8; Bush v. Brown, 49 Ind. 573, 578 (1875); Davis v. Luster, 64 Mo. 43 (1876); Phelps v. Zuschlag, 34 Tex. 371, 380 (I87o). See Inhabitants of Whitefield v. Longfellow, I3 Me. I46 (1836); Bowker v. Lowell, 49 Me. 429 (I86r). 
he had been advised of the informer's intent to do what the law makes it his duty to do. ${ }^{10}$ If the promise sued on was made to prevent a criminal prosecution of the one guilty of a felony, it is void because it is compounding a felony; ${ }^{11}$ if the one accused was innocent of the crime, an undertaking given in consideration that he should not be prosecuted has failed and likewise is unenforceable. ${ }^{12}$ To make a threat of lawful arrest a defense to an obligation assumed as a result thereof, its purpose must be unlawful, as it would be if the promisee threatens to pervert the machinery of the criminal law into an aid for the enforcement of a private right. ${ }^{13}$ Even though the threatened arrest was for an offense disconnected with the claim on which suit was brought, and the obligor was guilty of the crime alleged, such fear may nevertheless have been excited in his mind as to afford him a defense if suit is brought to recover on the contract made under such circumstances. ${ }^{14}$ A threatened lawful arrest, however, which does not imply unusual use of criminal process, without danger that the threat will be carried out immediately, does not seem to be within the inhibitions of the rule. ${ }^{15}$ A threat of prosecution without commencement of proceedings is not duress. ${ }^{16}$ The law

${ }^{10}$ Hilborn v. Bucknam, 78 Me. 482, 485, 7 At1. 272, 273 (1886).

${ }^{11}$ Rostad v. Thorsen, 83 Ore. 489 , I63 Pac. 423 , 987 (1917). But see contrary statement in City National Bank of Dayton v. Kusworm, 88 Wis. 188, 59 N. W. 564 (I894).

20 Smith v. Steeley, 80 Iowa 738,45 N. W. 912 (1890); Henry v. State Bank of Laurens, I3I Iowa 97, I07 N. W. 1034 (I906).

${ }^{23}$ The court says in Fountain v. Bigham, $235 \mathrm{~Pa} .35,46,84$ Atl. I3I, I35 (I9I2): “ . . a threat of lawful imprisonment is not duress, unless it is made for an unlawful purpose, such for instance, as compelling the satisfaction of a debt by payment in money or by execution of an obligation to secure it. If, in connection with the threat it appears that the creditor declared he would prosecute if the claim was not paid, with other evidence showing that his intention was to use the criminal process to collect the debt or to accomplish any unlawful purpose, a jury might well find that such was the purpose of the creditor in making the threat and that, thereiore, it was duress." Accord: Morse v. Woodworth, I55 Mass. 233, 25I, 29 N. E. 525, 528 (1892); (1910) Io CoL L. Rev. I64; Note, The Nature and Effect of Duress (1913) 26 Harv. L. REV. 255.

14 Thompson v. Niggley, 53 Kan. 664, 35 Pac. 290 (I894).

${ }^{25}$ Riney v. Doll, II6 Kan. 26, 225 Pac. I059 (I924); Higgins v. Brown, $78 \mathrm{Me} .473,5$ Atl. 269 (I886); Ball v. Ward, 76 N. J. Eq. 8, 74 At1. I58 (I909); Phillips v. Henry, $160 \mathrm{~Pa} .24,28$ Atl. 477 (1894); Wolf v. Bluhm, 95 Wis. $257,259,70 \mathrm{~N}$. W.'73, 74 (1897).

${ }^{10}$ Harmon v. Harmon, 6I Me. 227, 230 (1873); Dunham v. Griswold, Ioo N. Y. 224, 3:N. E. 76 (1885). 
respects freedom of the will, but if the method which overpowers the will is in all respects legal, in the weighing of interests this freedom must be subservient to the legal rights of the obligee. ${ }^{17}$

What is the legal effect of a threat to use legal process to seize goods in order to obtain a promise for the payment of money? Such a method of overpowering the mind was not mentioned by Coke as constituting duress per minas. The English view looked to the means and the reaction it might produce on one of ordinary firmness, but it did not consider the effect of the means upon the individual in question. It is but natural, therefore, that we find threats of injury to or imprisonment of the person constituted a defense, but injury to or an unlawful seizure of goods was not considered as depriving the owner of his freedom to give consent if he "possesses that ordinary degree of firmness which the law requires all to exert." 18 The early reasoning was that the individual might recover for the injury to or destruction of goods, but there could be no atonement for loss of life or limb or liberty. ${ }^{19}$ One whom nature failed to endow with the quality of "ordinary firmness" as determined by a jury of his peers was therefore bound by any promise he may have made under duress insufficient to overpower a man possessed of "ordinary firmness." So long as the court failed to find he had no mind to overcome, the promisor of inferior firmness would be without defense under the common law, no matter how nearly he might approach the lack of capacity usually attributed to a moron. Insanity, which would be a finding that he had no mind, would constitute a dif-

${ }^{17}$ See Pound, Interests of Personality (I915) 28 HARV. L. REv. 343. 359.

${ }^{18}$ Denman, C. J., in Skeate v. Beale, II A. \& E. 984, 990 (I84I). This view is in accord with SEEPPARD, Touchstone ( 1648 ) $6 \mathrm{r}$, which says: ". . . for danger to goods, \&c., is not regarded by the law, so far as to avoid a deed. .. for if it be only a threatening to take away goods, or to burn' a house, or the taking and keeping of a man's goods, or the like, this will not make the deed, made upon that occasion, to be per duress." This appears to be the view taken by at least one American jurisdiction, which denies that one of ordinary firmness could be affected by threats to his property. "Duress, according to its legal signification, is personal restraint, or a fear of personal injury, or imprisonment. The withholding a man's property illegally does not place him under fear or duress. For such an injury the law affords him ample remedy." Hazelrigg v. Donaldson, 2 Metc. 445, 447 (Ky. I359). See ANsoN, Contracts (I6th ed. I923) 220, (American ed. I924) \$ 228; Astley v. Reynolds, 2 Strange 916 ( 1732 ).

${ }^{20}$ I BL. Cosiar. *I3I. 
ferent kind of defense. Short of insanity, the common law held the promisor responsible for "ordinary firmness," and did not consider the effect of the duress upon the mind of the individual in question.

Since duress is now viewed subjectively, ${ }^{20}$ it is not surprising to find abandonment of the old pigeon-holes labelled by Coke as actual imprisonment, fear of loss of life, loss of member, and mayhem, and instead discover one compartment labelled "the effect upon the promisor" into which all cases may be placed. Obviously threat of the loss of goods could find no compartment marked by Coke; therefore, it could not be considered a defense. Modern authorities logically reach the result that a threat or attempt to seize goods may overcome the will so that an individual may do the physical act of signing an instrument, which his mind does not accompany ; ${ }^{21}$ and the fact that by redress at law he may protect his property will not necessarily bar the defense, ${ }^{22}$ though

${ }^{20}$ See Pound, Interests of Personality (I915) 28 HARV. L. REV. 343, 358359, especially note 49 therein. The modern viewpoint, contrary to the English, is thus expressed: "The test of duress is not so much the means by which the party was compelled to execute the contract as it is the state of mind induced by the means employed, - the fear which marle it impossible for him to exercise his own free will." Fountain v. Bigham, $235 \mathrm{~Pa} .35,45,84$ Atl. I3I, I35 (I9I2). Accord: Doose v. Doose, 300 I1l. I34, I38, I33 N. E. 49, 51 (I92I).

22 "We cannot forget the fact that the desire for property is a strong and predominant characteristic of man, in organized society. An act done, prompted by this desire to preserve, and impelled by fear of the destruction of goods, is not voluntary. It is an act of compulsion." Spaids v. Barrett, 57 III. 289, 292 (I870). Accord: Joannin v. Ogilvie, 49 Minn. 564, 52 N. W. 217 (I892). See test applied by Mr. Justice Field in Radich v. Hutchins, 95 U. S. 210, 213 (1877).

${ }_{22}^{2}$ Lonegran v. Buford, I48 U. S. 581, 590, I3 Sup. Ct. 684, 687 (1892); Foote v. De Poy, I26 Iowa 366, 370, 102 N. W. I12, II4 (I905); Chandler v. Sanger, II4 Mass. 364 (I874) ; Fargusson v. Winslow, 34 Minn. 384, 25 N. W. 942 (1885); Wilkerson v. Hood, 65 Mo. App. 491, 494 (I896); Stenton v. Jerome, 54 N. Y. 480,485 (1873); McPherson v. Cox, 86 N. Y. 472,479 (I88I); Note (IgI2) 6I U. of PA. L. REV. II9. While clinging to the effect it would have on "a person of ordinary firmness," the Pennsylvania court recognized that "where a party has the property of another in his power, so as to enable him to exert his control over it to the prejudice of the owner, a threat to use this control may be in the nature of the common-law duress per minas, and enable the person threatened with this pernicious control to avoid a bond or note obtained without consideration, by means of such threats." Mutz v. Mitchell, 9I Pa. II4, II7 (I879). Accord: Miller v. Miller, $68 \mathrm{~Pa} .486,493$ (I87I). But the financial difficulties of the promisor should not be considered in determining whether duress existed. Hackley v. Headley, 45 Mich. 569, 577 (I88I) ; Bartlett v. Richardson Co., I6I N. E. 403, 405 (Ohio 1927). In Sasportas v. Jennings, I Bay 470,475 (S. C. I795), note the reasoning that 
an instrument executed merely to prevent suit or in compromise of a claim could not be defeated upon the ground of duress. ${ }^{23}$ Nor is it duress to threaten disposal of the obligor's goods as the obligee was legally entitled to do. ${ }^{24}$

Without considering the consequences upon the mind of the promisor, the common law denied that threats of injury to or imprisonment of a third person could be a defense except in the one case of threats of injury to a wife. ${ }^{25}$ This exception was not based on the fiction of identity of the husband and wife, but was a recognition that such intimate relation will usually arouse the sympathy of the promisor, and threats against the life or liberty of the spouse are the same as threats against the life or liberty of the obligor. ${ }^{28}$ Such threats to father, brother, or child might affect some of the weaker folks, but evidently it was not comprehended that those of "ordinary firmness" could be influenced by threats or injuries to other relatives. The modern and more rationalistic view does not exclude the defense of threats of injury to or imprisonment of a third person so long as he bears a sufficiently close relationship by blood or marriage to the obligor that a jury might infer that the mind of the latter was overcome to the extent that it could not meet that of the obligee. ${ }^{27}$ In accord-

duress of goods will not avoid a man's contract if the person exerting the duress is able to compensate the owner, and there is a prompt and effectual method to compel this satisfaction. Approved in Collins v. Westbury, 2 Bay 2Ir (S. C. 1799). The same idea is expressed in Tucker v. State ex rel. Hart, 72 Ind 242,245 (I880).

${ }^{23}$ James v. Dalbey, I07 Iowa 463, 469, 78 N. W. 5I, 53 (1899).

2 Heald v. Crump, 73 Colo. 25I, 253, 215 Pac. I40, I4I (I923).

25 "It must be a threatning, beating or imprisonment of the party himself that doth make the deed, or of his wife; for if it be a threatning, beating or imprisonment of any other besides the party himself that doth make the deed or his wife, this will not make the deed to be by duress." SHEPPARD, TouchSTONE ( 1648 ) $6 \mathrm{I}$.

${ }^{28}$ Heaton v. Norton County State Bank, 59 Kan. 28I, 52 Pac. 876 (18g8); Harris v. Carmody, I3I Mass. 5I, 55 (I88I).

${ }^{27}$ See the majority opinion by Mr. Justice Holmes in Silsbee v. Webber, I7I Mass. 378, 50 N. E. 555 (1898), where it was said sufficient evidence existed that plaintiff's mind was overcome when it was shown that her son was accused of embezzling money, and the defendant threatened to tell her husband, the young man's father, whose physical condition was such that the promisor feared this knowledge would make him insane. With such feelings, the plaintiff assigned to the defendant her share in her father's estate. The fear of serious effects upon her husband's health, by informing him of the son's alleged crime, was sufficient to give the plaintiff the right to avoid her con- 
ance with this rationalistic view, we find courts admitting evidence of threats of injury to or imprisonment of the promisor's adult or minor child, ${ }^{28}$ father, ${ }^{29}$ adopted child who was a grandson, ${ }^{30}$ brother, ${ }^{31}$ son-in-law ${ }^{32}$ and nephew, ${ }^{33}$ as tending to show that the mind of the obligor was overcome and his act in signing was involuntary. ${ }^{34}$ Threats of prosecution of a brother-in-law should be resisted, one authority contends, and recovery may be had although the promise was made because of threats to the safety of such a relative. ${ }^{35}$ In case a contract is made because of threats of imprisonment to one whose relationship would excite the sympathy of the promisor and overcome his will, it is immaterial whether a lawful or unlawful imprisonment is contemplated. ${ }^{36}$

tract. The opinion, at $380,50 \mathrm{~N}$. E. at 556 , refuses to recognize "a general external measure for duress." But in Fonville v. Wichita State Bank and Trust Co., I6I Ark. 93, 255 S. W. 56I (1923), threats by a creditor to a debtor, whose debt was discharged in bankruptcy, that his failure to sign a note covering this discharged sum would incur the ill will of the payee bank, were held not to constitute duress, and insufficient to submit to the jury.

${ }^{2}$ O'Toole v. Lamson, 4I App. D. C. 276 (I914); Spoerer v. Wehland, I30 Md. 226, roo Atl. 287 (I917); Harris v. Carmody, I3I Mass. 5I (I88I); Kohler \& Chase Co. v. Savage, 86 Ore. 639, I67 Pac. 789 (I9I7); Owens v. Myatt, I Heisk. 675 (Tenn. 1870).

${ }^{20}$ Embrey v. Adams, 19I Ala. 29I, 68 So. 20 (1915).

${ }^{30}$ Bradley v. Irish, 42 Ill. App. 85 (189x).

${ }^{31}$ Travis v. Unkart, 89 N. J. L. 57I, 99 Atl. 320 (19r6) ; Schultz v. Catlin, 78 Wis. 61 I, 47 N. W. 946 (189I). See Davis v. Luster, 64 Mo. 43 (1876). ${ }^{32}$ Nebraska Mutual Bond Ass'n v. Klee, 70 Neb. 383, 97 N. W. 476 (I903); Fountain v. Bigham, $235 \mathrm{~Pa}$. 35, 84 Atl. $13 \mathrm{I}$ (1912).

${ }^{3}$ Town of Sharon v. Gager, 46 Conn. I89 (1878).

34 This was recognized by the following language from Spear v. Ryan, 64 Mont. 145, I50, 208 Pac. I069, I07I (1922): "There are certain exceptions to this rule (that duress of third persons is not available as a defense to the obligor), recognized by some but not by all of the authorities, in favor of a husband and wife, parent and child, and other persons sustaining such a close relationship to the threatened individual as that in fairness it may be said that the threats coerce their judgment and actions, and any one of these excepted classes may, under some authorities, avoid a contract made to relieve the other from duress."

${ }^{35}$ Union Exchange National Bank of New York v. Joseph, 194 App. Div. 295, 300, 185 N. Y. Supp. 403, 4C7 (1920), per Greenbaum, J., aff'd. on other grounds in 231 N. Y. 250, I3I N. E. 905 (I921). On what seems preferable reasoning in the opposite direction, see Port of Nehalem v. Nicholson, I22 Ore. 523,259 Pac. 900 (1927), and the comment thereon in (1928) I2 MiNN. L. REv. 409, 410, to the effect that courts now give "less consideration to the relationship and more to the sufficiency of the threat to coerce the mind of the person under duress."

${ }^{38}$ Averill Machinery Co. v. Taylor, 70 Mont. 70, 78, 223 Pac.. 918, 920 (1924); Adams v. Irving National Bank, II6 N. Y. 606, 612, 23 N. E. 7, 9 (1889); Gorringe v. Read, 23 Utah 120, 133, 63 Pac. 902, 905 (I901). 
It is possible for a bond not required by statute to have efficacy as a common law bond; ${ }^{37}$ but one prohibited by statute, ${ }^{38}$ or whose provisions are in excess of those authorized by law, ${ }^{39}$ or which is required by an official in order that the obligor may retain his liberty or property, but without legislative authority, is void. ${ }^{40}$ Some of the cases interpret the act of supererogation of a superior

${ }^{37}$ Lowe v. City of Guthrie, 4 Okla. 287, 293, 44 Pac. 198, 200 (I8g6) ; Duke v. National Surety Co., I30 Wash. 276, 227 Pac. 2 (I924).

${ }^{3}$ Aucoin v. Guillot, 1o La. Ann. I24, 125 (1855); Fisher v. Shattuck, 17 Pick. 252 (Mass. 1835); Thompson v. Lockwood, 15 Johns. 256 (N. Y. I818).

${ }^{2}$ Shuttleworth v. Levi, 13 Bush I95 (Ky. I877); Wooters v. Smith, 56 Tex. 198 (1882).

${ }^{10}$ U. S. v. Tingey, 5 Pet. II5 (U. S. I83I). In this case, a bond was required by a superior officer as a condition for the continuance of the principal in office. No bond was prescribed by law in such a case. Story, J., said, in the opinion at 129, that "no officer of the government has a right by color of his office to require from any subordinate officer, as a condition of holding-office, that he should execute a bond with a condition different from that prescribed by law." Accord: Hawes v. Marchant, Fed. Cas. No. 6,240 (1852).

Although the same court many years subsequently attempted to reconcile its position with U. S. v. Tingey, supra, it is rather difficult to comprehend any real basis for a distinction. In Howgate v U. S., 3 App. D. C. 277 (I894), the highest court of the District of Columbia had held it was not duress to require a bond from a public officer for a lawful purpose, though no statute required it. This case was reviewed by the United States Supreme Court sub. nom. in Moses v. U. S., I66 U. S. 57I, 17 Sup. Ct. 682 (1897), which considered the exclusion of evidence by the trial court. The evidence was offered by sureties on a bond to show that Howgate, the principal, who was acting signal officer, was required by the Secretary of War to give a bond, without statute or regulation permitting it; and the Secretary further threatened to relieve Howgate if he failed to give a bond. The sureties contended this evidence showed the bond was void as being exacted colore officii. The Supreme Court, in affirming the rejection of the evidence by the Court of Appeals of the District of Columbia, said at 586 , I7 Sup. Ct. at 687 : "It was held in the case of United States v. Tingey, 5 Pet. II5, that the United States had a right to take a bond to insure the faithful performance of duty on the part of an individual or officer where such bond was voluntarily given, and was not in violation of any provision of law. The particular bond in that case was held void as being extorted under color of office because it was in plain violation of the statute in regard to giving such bond, and it was demanded of the party upon the peril of losing his office. . . We do not understand by the decision in Peters, above cited, that the meaning of the term 'voluntary bond' is that the bond must have been offered and pressed upon the Government when never asked for or demanded by it. It is a voluntary bond when it is not demanded by any particular statute or regulation based thereon, and when it is not exacted in violation of any law or valid regulation of a department. Having the right to take a bond, the Government in a case like this has the right to demand it from the officer, and to say to him that if he do not give it he will not be continued as a 'property and disbursing officer of the Signal Service.' Such a demand when complied with does not amount to the illegal exaction or extortion of the bond. The case of a bond so procured differs radically from a case like that of Tingey (supro), inasmuch as the bond in the latter case was extorted from a reluctant officer with a condition therein contained different from that which the statute called for." 
officer in requiring a bond, when in excess of the authority of the law, as illegal, while others regard it as duress colore officii. ${ }^{41}$

\section{Fraud and Duress Compared}

If the contract is induced by fraud, is the legal result the same as if it had been induced by means of duress? The idea of physical force, or compulsion by employing legal process, is associated with duress. The mind may be overcome by acts which do not involve physical violence or the institution of legal proceedings. Coercion may be "a social, moral, or domestic force . . . exerted on a party, which controls the free action of his will." 42 Mr. Justice Holmes has suggested that the effect on a contract made by the obligor is the same whether induced by duress or fraud; that "whether it springs from a fear or from a belief, the party has been subjected to an improper motive for action." 43 It is evident that if the fraud consists of procuring the consent of a person to something other than it actually is, whether the means used is a representation, ${ }^{44}$ or silence when the obligee should have spoken, ${ }^{4 \mathbf{5}}$ the effect is the same as if duress had been employed in overcoming the mind of the obligor. Fraud and duress are but different means employed to accomplish the same thing; therefore, the effect of the use of either should be tested by the same standard, namely, the reaction upon the particular obligor. ${ }^{46}$

"See Ferry v. Burchard, 21 Conn. 597 (1852) ; Clinton v. Strong, 9 Johns. 370 (N. Y. 1812 ).

${ }^{2}$ Munson v. Carter, I9 Neb. 293, 302, 27 N. W. 208, 212 (1886). Accord: Jones v. Rogers, $36 \mathrm{Ga}$. I57 (1867) ; Macke v. Jungels, 102 Neb. 123, 124, 166 N. W. IgI, I92 (Ig18).

4 Fairbanks v. Snow, I45 Mass. I53, I54, I3 N. E. 596, 598 (I887).

" Satterfield v. Spier, II4 Ga. I27, 39 S. E. 930 (rgor) ; Bennett v. Corey, 72 Iowa 476,34 N. W. 291 ( 1887 ) ; Macey, Henderson \& Co., Ltd. v. Heger. 195 Pa. I25, 45 Atl. 675 (1900); Rowlatt, Principal aNd Surety (I927) I57.

15 "It is not essential, to constitute fraud, that there should be any misleading by express words; it is sufficient if it appears that the plaintiffs knowingly assisted in inducing the defendant to enter into the contract, by leading him to believe that which the plaintiffs knew to be false, the plaintiffs knowing that, if he had not been thus misled, he would not have entered into the contract." Lee v. Jones, I7 C. B. N. S. 482, 507 (1864). Accord: Railton v. Mathews, Io Cl. \& F. 934 (1844); London General Omnibus Co., Ltd., v. Holloway, [1912] 2 K. B. 72; Bank of Monroe v. Anderson Bros. Mining \& Ry., 65 Iowa 692,22 N. W. $929(1885)$.

${ }^{46}$ "Now we are not able to see what distinction there could be in fact, between a note, the signature to which was obtained by fraud, and one where 


\section{Fraud or Duress by a Third Person}

Suppose the obligor becomes a party to an undertaking because of the duress or fraud of a stranger, and without the knowledge or fault of the obligee, may the obligee recover thereon? Here both the obligee and obligor are innocent, and one of two innocent parties must suffer for the act of the stranger. The effect upon the obligor's mind may not be different if the duress consisted of taking his hand and forcibly tracing his signature, or at the point of a gun forcing him to sign, or unlawfully threatening him with imprisonment, or giving him cause to fear for the safety of his wife or child; and it may be a matter of indifference to the obligor whether such means were employed by a stranger or the obligee. But it is obvious that the obligee's innocence of duress or fraud makes it inequitable that he should suffer in some cases where fraud or duress is applied by a third person without the obligee's knowledge or consent.

It was said in an early case ${ }^{47}$ that "if a stranger menace $A$ to make a deed to $B, A$ shall avoid the deed which he made by such threats, as well as if $B$ himself had threatened him, as it is adjudged 45 E. III 6, a." As a statement of a general rule applicable to all types of duress or fraud, this is not acceptable. Some means of duress employed by a stranger, where no fault is attributable to the obligee, can afford no defense to the obligor. The inequity is apparent. The effect of fraud or duress by the stranger upon the obligor subjectively may be the same as if the obligee had been responsible for it. But the subjective test, while applicable where the question arises between those who are parties to the fraud or duress, and in some cases where applied by a third person, cannot be urged as against the obligee in many cases where a third person has overcome the promisor's mind. Mr. Justice Holmes seems to acknowledge this when he asserts that there is "no distinct adjudication of binding authority that mere threats by a stranger, made without knowledge or privity of the party, are

the signature was obtained by duress." Clark v. Pease, 4I N. H. 4I4, 425 (I860). This accords with Dean Ames' statement in Specialty Contracts and Equitable Defenses (1895) 9 HARV. L. REv. 49, 58, that "whatever its origin, the defense of duress does not differ in its nature from the defense of fraud."

${ }^{67}$ Thoroughgood's Case, 2 Co. Rep. 9a, 9b, 6 Eng. Rul. Cas. 202, 203 (1582). 
good ground for avoiding a contract induced by them"; but on the previous page by obiter he admits that if a stranger had taken the hand of the defendant and compelled him to hold the pen and write his name, and had delivered the instrument-a promissory note-"no contract would have been made, whether the plaintiff knew the facts or not." 48 Dean Wigmore admits that by forcible movement of the pen in the hands of another, the volition of the writer is lacking, and the act is not binding because there was no opportunity for him to exercise his will. ${ }^{49}$ In this case, the duress would amount to a forgery, and would be a real defense; ${ }^{50}$ but although equivalent to a forgery, a bank would seem to be protected if it innocently paid a check signed by the drawer under circumstances making him a mere automaton for someone else. ${ }^{51}$ While it is true, as a general rule, that "duress by a stranger cannot, therefore, be successfully pleaded in bar of an action by an innocent obligee," 52 if that duress is of such character that it prevents him from applying his mind, and makes of him a machine for registering the dictates of another, it seems he has a defense which presents a superior equity to that of the obligee. If the will acts prompted by duress or fraud applied by a third person, the obligor is bound because the obligee had every reason to believe the obligor consented and it would be inequitable to deny him the benefit of his contract. ${ }^{53}$ Threats of prosecution conveyed to a surety by a principal without knowledge of the obligee cannot be (1887).

${ }^{2}$ Fairbanks v. Snow, 145 Mass. 153, I54, I55, I3 N. E. 596, 598, 599

5 WigMore, Evidence (ig23) \$2423. See WinListon, SaIEs (2d ed. 1924) \$658. In Barry v. Equitable Life Insurance Co., 59 N. Y. 587,592 (I874), it is said: "But where there exist coercion, threats, compulsion and undue influence, there is no volition. There is no intention nor purpose, but to yield to moral pressure, for relief from it. A case is presented more analogous to a parting with property by robbery. No title is made through a possession thus acquired."

${ }^{5}$ Ogden, Negotiable Instruments (2d ed. 1922) § I39.

${ }^{51}$ Southern Hardware and Supply Co. v. Lester, I66 Ala. 86, 93, 52 So. 328, 33 (I9I0); State v. Wegener, I80 Iowa 102, II9, I62 N. W. 1040, I046 (I917). ${ }_{52}$ Ames, Specialty Contracts and Equitable Defenses (1895) 9 Harv. L. REv. 49, 58. See Anonymous, Keilw. 154, pl. 3 (1510).

83 "His will acts, although the duress constitutes the motive for his action." Harriman, Contracts (2d ed. IgOI) § 444. The French Civil Code permits avoidance of a contract in case violence is used by a stranger to the contract. See Cacharp's Transtation (I895) §iIII. 
said to afford him any defense, though because of relationship with the principal his mind was overcome. ${ }^{54}$ That the one who was guilty of fraud or duress was the principal, whose act under doctrines of agency could not be attributed to the obligee, is immaterial. Wrongful conduct between co-makers not participated in by the obligee gives the obligor no more defense than if a stranger had perpetrated it. ${ }^{55}$ In any case, however, where the obligor's will was prevented from asserting itself, it is not equitable to permit the obligee, though innocent, to recover.

\section{Negotiability as Affecting the Defenses of Fraud and DURESS}

The assignee of a non-negotiable contract takes it subject to such defenses as would be a bar to the assignor had the action been between the original parties. ${ }^{56}$ But suppose the duress or fraud is imposed on the maker of a promissory note or the drawer of a bill of exchange, is the rule any different because the instrument is negotiable? In determining whether there is or is not duress the character of the undertaking calls for application of no different rule, and if the act of the obligee constitutes duress, the defense is available in a controversy between the original parties, (IgI8).

Brady v. Equitable Trust Co., I78 Ky. 693, 701, I99 S. W. 1082, I086

${ }^{5}$ Rutland v. Parham, 32 Ga. App. 662, 124 S. E. 355 (I924); Anderson v. Warne, 7I Ill. 20 (1873); Davis Sewing Machine Co. v. Buckles, 89 Ill. 237, 243 ( I878) ; Page v. Krekey, I37 N. Y. 307, 33 N. E. 31 (1893) ; Dunfee v. Dunfee, I45 App. Div. 108, I29 N. Y. Supp. I42 (Ig0I), aff'd., 205 N. Y. 543, 98 N. E. 1102 ( I912) ; Damon v. Empire State Surety Co., I6r App. Div. 875,146 N. Y. Supp. 996 (I9I4). It was held to be no defense to the wife, as surety for her husband, that he threatened to kill himself if she failed to sign the note upon which suit was brought. Wright v. Remington, 4I N. J. I. 48 ( 1879 ).

It was said in Potts v. First State Bank of Talhina, 51 Okla. 162, I66, I5I Pac. 859, 860 (I9I5), that "fraud on the part of the principal maker of a promissory note whereby his surety is induced to sign it, knowing it to be a note, will not relieve the surety of liability to the payee if the payee did not know or have notice of the fraud at the time he accepted the note for a valuable consideration." Accord: Lucas v. Owens, I13 Ind. 52I, 16 N. E. I96 (1888); Shepard Land Co, v. Banigan, 36 R. I. I, 87 Atl. 531 (I9r3) ; Cimini v. Zambarano, 36 R. I. I22, 89 Atl. 295 (19I4), opinion amended upon another point in 89 Atl. 7Ir (19I4); Atlantic Trust \& Deposit Co. v. Union Trust \& Title Corp., Iro Va. 286, 292, 67 S. E. I82, I84 (I909).

${ }^{60}$ Barry v. Equitable Life Assurance Soc., 59 N. Y. 587 (1874). 
whether the instrument be negotiable or not. ${ }^{57}$ But once it comes into the hands of a holder in due course, fraud or duress by a stranger or the payee will not constitute a defense to the one primarily liable thereon unless it is of such character as to make the instrument void for all purposes. ${ }^{58}$ ". . . . it is void as between the parties, but not absolutely void as to innocent purchasers without notice, who, in the ordinary course of business, took it in good faith and paid a valuable consideration." ${ }^{59}$ One taking a negotiable instrument procured by fraud has the burden to prove that he is a holder in due course. ${ }^{60}$

\section{Fraud or Duress Upon the Principal as a Defense to the SURETY OR GUARANTOR}

When duress or fraud of the obligee is responsible for the principal's non-negotiable undertaking, the surety or guarantor thereon frequently attempts to take advantage of it on the theory that without a principal who is bound, a surety or guarantor cannot be liable. Whether the doctrine of $j u s$ tertii applies here is a controverted point. In discussing this proposition, the surety and guarantor will be considered separately, for their contracts are entirely different. The surety becomes jointly or severally

57 " $\mathrm{But}$ in cases of duress, fraud, or circumvention, the fault was all upon one side, and the innocent party, upon whom the duress or the fraud was practiced, may not only avoid the contract entered into under these circumstances, but if he pay money, or deliver property, he may recover it back again. Now bills and notes stand upon the same foundation as all other contracts do in all the above respects so long as they remain in the hands of the original payee." Clark v. Pease, 4I N. H. 4I4, $42 \mathrm{I}$ (I860).

ss See Brannan, Negotiable: Instruments Law (4th ed. 1926) 432-433.

${ }^{60}$ State v. Wegener, I80 Iowa 102, 123, 162 N. W. 1040, 1047 (I9I7). Accord: Metropolitan State Bank v. McNutt, 73 Colo. 29I, 215 Pac. 15I (1923); First National Bank v. McGrath Sons Co., III Miss. 872, 72 So. 701 (I9I6); Danies, Negotiabie InStruments (I9I3) $\$ \$ 857-858$; OGDEN, Negotiable INSTRUMIENTS (2d ed. I922) \$§ I42-I43. See Everding and Farrell v. Toft, 82 Ore. I, I60 Pac. Ir6o (I916); Jewel Tea Co. v. Weber, I59 Wis. 543 , 150 N. W. 956 (1915).

${ }^{60}$ Woodsmall v. Myers, 158 N. E. 646 (Ind. App. I927) ; Downs v. Horton, 287 Mo. 4I4, 230 S. W. I03 (I92I); Gebby v. Carrillo, 25 N. M. I20, I77 Pac. 894 (I9I8); Leavitt v. Thurston, 38 Utah 35I, II3 Pac. 77 (I9II). As to meaning of "burden" as used in N. T. L. \$ 59, assumed by a "holder" to prove that he or one under whom he claims is a "holder in due course" as defined in N. I. L. \$ 52, see Chafee, Progress of the Laze-Bills and Notes (1919) 33 HARv. L. REv. 255, 274; Comment (1926) I IND. L. Rev. 49; Honigman, Proof of Good Faith (r925) 23 Mich. L. Rev. 870; (1922) 6 MinN. L. Rev. 313; Daniel, Negotiable Instruments (I9I3) §§ 166, 8ig. 
bound with the principal on his contract, the same consideration supporting both, and his liability is absolute, beginning whenever the principal becomes liable. The guarantor cannot be jointly liable with the principal, his promise requires separate consideration to give it vitality, and his liability begins for the first time on the default of the principal. ${ }^{61}$

The cases involving the surety's plea of non-liability of the principal as his defense are of three classes: First, those in which the principal's defense is personal, such as incapacity to contract, ${ }^{62}$ his discharge in bankruptcy, ${ }^{63}$ insanity, ${ }^{64}$ ultra vires contracts of a corporation which is principal, ${ }^{65}$ an oral promise by a principal unenforceable because required to be in writing by the statute of frauds. ${ }^{66}$ Although the principal might prevent recovery against himself by the creditor in each of these cases, the surety or guarantor could not plead successfully any one of the defenses mentioned. Second, cases involving defenses inhering in the primary obligation of the principal, as in a contract given in consideration of forbearance to prosecute the principal, ${ }^{67}$ or an undertaking prohibited by law, ${ }^{68}$ or if it is violative of public policy, ${ }^{69}$ or if the consideration fails as between the obligee and

a The writer has attempted to make these distinctions more in detail in his recent text OUTLINES OF SURETYSHIP AND GUARANTY (1927) $\$ \S 7-8$. See the differentiation in (1927) 21 ILL. L. REv. 637; Note (1918) I8 CoL L. REv. I58; Arnold, Primary and Secondary Obligations (1925) 74 U. oF PA. L. Rev. 36, 41-45; Goodrich Rubber Co., Inc., v. Fisch, I4I Va. 261, I27 S. E. I87 (1925). e. incapacity of the principal party promising to make a legal contract, if understood by the parties, is the very defense on the part of the principal against which the surety assures the promisee." Winn v. Sanford, I45 Mass. 302, 304, I4 N. E. II9, I2I (1887). Accord: Gates v. Tebbetts, 83 Neb. 573, IIg N. W. II20 (I909).

${ }^{\infty}$ Wolf v. Stix, 99 U. S. I (1878); Phillips, Burtoff \& Co. v. Wade, 66 Ala. 53 (I880); Cochrane v. Cushing, I24 Mass. 219 (1878).

a Burner v. Nutter, 77 W. Va. 256, 87 S. E. 359 (I915) ; Lee v. Yandell, 69 Tex. $34,35,6$ S. W. 665,667 (I887).

¿ Weare v. Sawyer, 44 N. H. I98 (1862) ; Bell v. Kirkland, I02 Minn. 213,

II3 N. W. 27I (I907); Mason v. Nichols, 22 Wis. 360 (I867).

${ }^{e}$ Backhus v. Feeks, 7I Wash. 508, 129 Påc. 86 (1913).

${ }^{\theta 7}$ Jones v. Merionethshire Permanent Benefit Building Soc., [18gr] 2 Ch. 587, aff'd., [1892] I Ch. 173; Singer Mfg. Co. v. Ferrell, $20 \mathrm{Ky}$. L. Rep. I20I, 48 'S. W. 1078 (1899); Union Exchange National Bank v. Joseph, Ig4 App. Div. 295, I85 N. Y. Supp. 403 (I920), aff'd., 23 I N. Y. 250, 13I N. E. 905 (I92I).

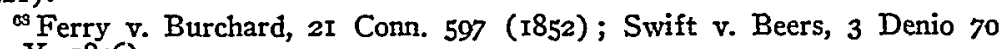
(N. Y. I846).

Denison v. Gibson, 24 Mich. 188, 202 (1872). 
the principal, ${ }^{70}$ or the consideration is illegal. ${ }^{71}$ In such cases, the undertaking to which the surety has set his hand has no more efficacy than so much blank paper, and he may plead with success these inherent defenses. ${ }^{72}$ Third, that large group of cases which courts dispose of upon purely equitable considerations, which are peculiarly applicable to the relationship between principai, surety and obligee. ${ }^{73}$

Suppose the contract of the principal was entered into because of the fraud or duress of the obligee, is the surety, as distinguished from the guarantor, entitled to avail himself of the principal's defense under the jus tertii doctrine? Before analyzing the cases, which it is hoped may explain some conflicting views, it may be said the authorities have answered the above question both negatively and affirmatively. ${ }^{\text {i4 }}$

As discussed previously, duress or fraud imposed on an obligor by the obligee so that it overcomes his mind is a defense available to the former. An undertaking assumed by a principal through fraud or duress has the formal elements of a contract, but lacks one requisite, namely the freedom of will necessary to enable the mind of the obligor to meet that of the obligee. Is this

"Adams v. Cuny, I5 La. Ann. 485 (1860) ; Sawyer v. Chambers, 43 Barb. 622 (N. Y. 1864) ; Gunnis, Barrett \& Co. v. Weigley, II4 Pa. I9I, 6 At1, 465 (I886). While the one setting up the defense in the last two cases cited was the accommodation indorser, he was there regarded as a surety. Under the Negotiable Instruments Law, an accommodation indorser cannot be considered by the holder as a surety, but is an indorser, and the law governing indorsers applies to him. N. I. L. $\$ \S 63-64$.

7 Gill v. Morris, II Heisk. 6I4 (Tenn. I872).

i2 "The distinction which has been pointed out, vis., that inability on the part of the principal to contract is no defense to the guarantor, while fraud in the contract is, may be found in the civil law. This says that personal defenses do not pass to others, but that defenses, inherent in the thing, such as, among others, fraud and duress, are available to sureties." Putnam v. Schuyler, 4 Hun 166, I7I (N. Y. 1875).

"When no action is maintainable against the principal because of the inherent nullity of the alleged obligation sued on, no action can be maintained against sureties on such obligation, for a surety is only bound for the acts of his principal, and, if there were no principal there could not be a surety." Crum v. Wilson, 6r Miss. 233, 236 (1883). Accord: Ferry v. Burchard, 21 Conn. 597 ( 1852 ).

See Note, Liability of a Surety When the Principal Obligation is Unenforceable (1913) 13 CoL. L. Rev. 426.

74 See BrandT, Suretyship (3d ed. 1905) § 21 ; I Page, Contracts (I919) $\S 502$; SPENCER, SURETYSHIP (I913) § 57 ; STEARNS, SURETYSHIP (3d ed. Ig22) $\S 14$. 
in point with those cases of the second class, such as the failure or illegality of the consideration? If we conclude that a contract made by its principal obligor whose mind was overcome by fraud or duress is void, necessarily it never existed in law, it never had vitality, the fraud or duress cannot be waived by him or any other person, and in consequence a surety whose name was signed thereon was never bound. If, however, the undertaking may be said to be voidable, fraud or duress upon the principal is waivable by him, and so long as the contract is not avoided, the surety is not released.

It is certainly the English view that $j u s$ tertii is not available to a surety whose principal's contract was entered into because of fraud or duress of the obligee, ${ }^{75}$ and a fortiori it must follow that duress on the principal by a stranger should, under this view, have no effect upon the surety. ${ }^{76}$ American jurisdictions in which cases are found giving support to this view are Illinois, ${ }^{77} \mathrm{Ken}-$ tucky, ${ }^{78}$ Maine, ${ }^{78}$ Massachusetts, ${ }^{80}$ Montana, ${ }^{81}$ and North Carolina. ${ }^{82}$ Contra, a number of cases have held that a surety may interpose the defense that the principal's undertaking had its in-

70 "... it was not any plea for the surety, although it had been a good plea for the said Street; for none shall avoid his own bond, for the imprisonment or danger of any other than of himself only; and although the bond be avoidable as to the one, yet it is good quoad the other." Huscombe v. Standing, Cro. Jac. 187 (I608).

${ }^{70}$ See the quaintly reported case of Mantel v. Gibbs, I Brownl. \& G. 64 (1254), where in an action of debt, defendant pleaded that he became surety of a stranger who had been imprisoned by another until he made this bond: "and it was held a naughty plea, and a repleader awarded," says the report in all dignity. See what is apparently the same result in Wayne v. Sands, 3 Keb. 238 (1673).

7 Plummer v. People, I6 Ill. 358 (I855).

${ }^{78}$ Jones v. Turner, 5 Litt. 147 ( $\mathrm{Ky}$. I824). It is to be noted that there was a statute at the time of this case making yoid all contracts taken under color of office in any manner or form other than directed by statute. The sureties might have defended upon the ground that the bond exacted was prohibited by statute, without relying upon the reasoning stated in the opinion at I49, that "a bond executed by sureties, whilst under no duress, is valid and binding as to them, though it may not be valid as to the principal, in consequence of his being under duress at the time it was executed by him." Also see Thompson v. Buckhannon, 2 J. J. Marsh. 4I6 (Ky. 1829).

Oak v. Dustin, 79 Me. 23, 7 Atl. 8I5 (I887).

${ }^{80}$ Robinson v. Gould, II Cush. 55 (Mass. 1853); Bowman v. Hiller, 130 Mass. 153 (188I).

suear v. Ryan, 64 Mont. I45, 208 Pac. I069 (Ig22).

Simms v. Barefoot's Executors, 3 N. C. 402 (1806). 
ception in fraud or duress. Such a view has been sanctioned by courts in Alabama, ${ }^{83}$ Connecticut, ${ }^{84}$ Georgia, $^{85}$ Indiana, ${ }^{86}$ New Jersey, ${ }^{87}$ New York, $^{88}$ South Carolina, ${ }^{89}$ and West Virginia. ${ }^{80}$ Under the latter cases, to enable the surety to plead the fraud of the principal, it must be of such character as would, if he elected to set it up as a defense, be available to the principal. ${ }^{91}$

Different situations presented by the various cases must be kept in mind, for they are not so irreconcilable as might be supposed. For instance, threat of arrest of the principal may constitute duress upon him only, yet if the principal is closely related to the surety, as a nephew ${ }^{92}$ or son-in-law, ${ }^{93}$ the duress imposed by the obligee may avoid the agreement, not because the surety may take advantage of the principal's defense, but because the surety's mind was overcome, and hence he has an independent defense. In such a case, the duress is directly upon the surety,

State v. Brantley, 27 Ala. 44 (1855).

${ }^{3}$ See Town of Sharon v. Gager, 46 Conn. I89 (I878); Mills v. Swords Lumber Co., 63 Conn. 103, 26 Atl. 689 (1893).

${ }^{*}$ Patterson v. Gibson, 81 Ga. 802, 10 S. E. 9 ( 1889 ).

${ }^{68}$ Coffelt v. Wise, 62 Ind. 451 (1878).

${ }^{87}$ Schuster v. Arena, 83 N. J. L. 79, 84 Atl. 723 (19I2).

${ }^{\$}$ Strong v. Grannis, 26 Barb. 122 (N. Y. 1857) ; Osborn v. Robbins, 36 N. Y. 365 (1867). But see the more recent view, where this earlier case was cited, but apparently distinguished, in Ettlinger v. National Surety Co., 221 N. Y. 467 , II7 N. E. 945 (I917).

${ }^{5}$ Evans v. Huey, I Bay I3, I4 (S. C. 1784).

${ }^{80}$ "While not in accordance with the general rule that the defense of duress is a personal defense available only to the person upon whom it is imposed, it is held in a majority of jurisdictions that duress practiced upon the maker of a note may also be taken advantage of by the surety who in ignorance thereof has indorsed the instrument." Bank of Clinchburg v. Carter, Ior W. Va. 669, 673 , 133 S. E. 370, 371 (1926).

${ }^{21}$ Bryant v. Crosby, $36 \mathrm{Me}$. 562, 571 (1853).

22 Town of Sharon v. Gager, 46 Conn. 189 (1878).

23 "The reason for avoiding a contract on the ground of duress, as appears above, is that the condition of mind of the party upon whom the duress is imposed is such as to deprive him of the exercise of his free will. Whatever influence produces such a condition of mind will invalidate a contract executed while the influence prevails. The relations between parent and child and husband and wife are so close and tender that the law recognizes that threats to imprison one will have substantially the same effect on the mind of the other; and what will deprive the one of the free exercise of his will or judgment will have a like effect on the other. The reason of the rule will extend it to the case of a mother-in-law and son-in-law, where the latter is living amicably with his wife, and the two families are on the usual terms of intimacy and friendship. . . " Fountain v. Bigham, $235 \mathrm{~Pa}$. 35, 47, 84 Atl. I3I, I35 (1912). Accord: Spear v. Ryan, 64 Mont. I45, 150, 208 Pac. ro69, IO7I (1922). 
and resort to reasoning that he should or should not be permitted to plead defenses available to the principal is unnecessary; for it is well settled that the slighest fraud or duress by the obligee upon the surety touching his contract annuls it. ${ }^{94}$ In other cases, what the court has stated concerning the surety's right to set up the defense of fraud or duress as the principal might do, is obiter. ${ }^{95}$

As before observed, some of the courts permit the surety to interpose the defense that the obligee was guilty of fraud or duress on the principal, causing his mind to be overcome. The same defense seems logical if the contract is illegal. But no court would relieve a surety whose principal was insane, a minor, or incapacitated to make a contract. Some courts classify defenses as personal and those which are inherent. ${ }^{96}$ Another way of saying the same thing is that the surety may not take advantage of a defense which renders his principal's contract voidable merely, but he may urge that the contract was void from the beginning. We are compelled to determine in each case, therefore, not whether the defense is the capacity of the principal to contract, but whether the principal ever made any contract at all. One may. conceive of duress so flagrant that it would make the act void, as if the obligee or a stranger traced the signature of the principal

* Magee v. Manhattan Life Insurance Co., 94 U. S. 93 (I876); Ham v. Greve, 34 Ind. I8 (1870); Sewell v. Breathitt Lodge No. 649 , F. \& A. M., 150 Ky. 542, I50 S. W. 677 (I912); Peoples' State Bank v. Hill, 210 Ky. 222, 275 S. W. 694 (1925); Waterbury v. Andrews, 67 Mich. 28r, 288, 34 N. W. 575, 578 (1887); Weed v. Bentley, 6 Hill 56 (N. Y. I843); Putney v. Schmidt, I6 N. M. 400 , 120 Pac. 720 (I9II) ; McIntosh v. Dakota Trust Co., 52 N. D. 752, 204 N. W. 818 (1925); State Savings \& Trust Co. v. Grady, 20 Ohio App. 385 , I53 N. E. 238 (I923). Differentiating between a promise of the surety to perform the identical act the same as the principal and a promise to pay a debt owed by the principal, the writer of the recent note in (1927) 2 I ILI. L. REv. 637, 638 says: "The surety may successfully defend only when he possesses a defense and this defense must arise out of his contract with the creditor."

${ }^{\infty 6}$ For an example of obiter, see Whitcomb v. Schultz, 223 Fed. 268, 278 (C. C. A. 2d, I915).

$\infty 6$ "The exception is that where the principal is excused from liability for reasons personal to himself, and which do not affect the debt he has incurred, or the promise he has made, the surety would not be entitled to the benefit of this excuse .. This rule is not applicable here for we have already determined that the bond in the instant case is invalid because it was not supported by any consideration." Brown v. American Surety Co., IIo Okla. 253, 255, 237 Pac. 594, 596 (1925).

"Mere personal defenses enure to the benefit of the principal obligor only; the surety in a certain sense becomes the real sponsor for the indebtedness assumed." Burner v. Nutter, 77 W. Va. 256, 258, 87 S. E. 359, 360 (I9I5). 
by forcibly guiding his hand, effecting the same result as if his name had been forged. ${ }^{97}$ No vitality could be given the act by ratifying it or waiving the defense. Likewise fraud which induces the principal to believe the act which he is doing to be other than it is, is a defense; but fraud which induces him to assent to something to which, had he known the truth, he would never have assented, renders the act voidable. ${ }^{98}$ Thus it is seen that duress and fraud may prevent any contract from being made, or their existence may be urged for setting aside a contract made because the consent of the obligor was improperly obtained. ${ }^{99}$

Courts have not gone so far as to say that mere threats of personal danger to the principal, his imprisonment, or injury to his property, make a contract entered into by reason thereof entirely void, even in cases arising between the obligee and the principal. The defense may be waived. Most decisions which permit the surety to set up a defense inherent in the transaction overlook that the duress or fraud on the principal by the obligee usually makes the undertaking voidable but not void. ${ }^{100}$ If the

${ }^{n}$ See Note, The Nature and Effect of Duress (1913) 26 HARv. L. REv. 255; 5 Wigmore, Evidence (1923) \$ 2423; 3 WIIliston, Contracts (I920) \$ I622; Fairbanks v. Snow, I45 Mass. I53, I54, I3 N. E. 596, 598 (I887). This overpowering force was evidently found to have existed in the early case of Evans v. Huey, I Bay 13 (S. C. I784), where some time after the payee of a note had stabbed the principal, he came to the principal's home at a late hour and proposed as a basis for settlement of their differences that a note be given for $£ 28$. No threats were made on the latter occasion, but the principal was yet under the influence of the previous attack. The next morning the payee took the note to a neighbor who signed as surety. The court held this note was void against botn principal and surety.

${ }^{98} 3$ Williston, Contracts (I920) § I488; Williston, Sales (2d ed. I924) \$ 625. See Foster v. Mackinnon, L. R. 4 C. P. 704 (I869); First National Bank v. Hall, I69 Iowa 218, 221, I5I N. W. 120, I22 (1915); National Exchange Bank v. Veneman, 43 Hun $24 \mathrm{I}$ (N. Y. I887); Security Finance Co. v. Comini, Irg Ore. 460, 467, 249 Pac. 1054, I056 (I926); Norton, BIILS AND Notes (4th ed. Igr4) 355-364.

${ }^{80} 3$ WILLISTON, CoNTRACTS (1920) § I6z2.

${ }^{100}$ Knowlton, J., in Morse v. Woodworth, 155 Mass. 233, 25I, 29 N. E. 525,528 (I891), said: "A contract obtained by duress or unlawful imprisonment is voidable." See the note in (I920) 5 CoRN. L. Q. 214, 215, which says: "According to the law of contracts a contract induced by fraud or duress is not void, but voidable by the party upon whom the fraud or duress is practiced. And this being true of contracts generally, it is applicable likewise to agreements where there is a surety." 3 Williston, Contracts (I920) § 1623 ; Royal v. Goss, 154 Ala. II7, I2I, 45 So. 23I, 232 (I907); Bush v. Brown, 49 Ind. 573, 577 (1875); Brenard Mfg. Co. v. Stuart, 212 Ky. 97, 102, $278 \mathrm{~S}$.' W. 586, 588 (1925) ; Colon \& Co. v. East $189 t h$ St. Building and Construction Co., I 4 I App. Div. 44I, 442, I26 N. Y. Supp. 226, 227 (I910). 
contract is voidable only, should the surety avail himself of the defense of fraud or duress in its creation, though the principal may see fit to waive it as against him? ${ }^{101}$

While the facts are not clear in every case, some opinions take the position that "he only should be allowed to avoid his contract, upon whom the unlawful restraint or fear has operated." 102 Such a view logically denies the admission of evidence that the principal signed under duress, for, admitting his duress by the obligee, it will not defeat a promise of the surety voluntarily made. ${ }^{103}$

What is the logical result of denying the surety the right to plead the jus tertii in such a case? The surety must pay, although the principal is relieved from any action by the obligee. The surety is entitled to be reimbursed for all money expended for his principal. When the obligee collects from the surety, the latter may then recover indemnity from the principal from whom the creditor can collect nothing, thus permitting the obligee to accomplish indirectly that which by his duress he has prevented himself from accomplishing directly. If the surety is denied reimbursement, he will be deprived of a fundamental right given a surety. So, to say that the surety in no case may set up the duress or fraud of the principal, though many cases hold just that, is illogical and unjust. $^{104}$ This solution applied by many courts, perhaps the majority, is not satisfactory.

Let us see what is the effect of an unrestricted rule permitting the surety to set up the duress or fraud of the obligee upon the principal. Unless of extraordinary character, duress or fraud

201 "In the case of a voidable contract, the acts of the parties, even when they are mere words, operate to create new legal relations, and these are in a measure the ones contemplated by the parties. They are usually described as rights and duties, privileges and powers, etc., just as in the case of a valid contract; but one of the parties has the additional power and privilege of extinguishing them. The exercise of this power is described as the disaffirmance or avoidance of the contract. Another way of describing a voidable contract is to say that the contemplated contractual relations do not yet exist, but that one of the parties has an irrevocable power to create them. His subsequent act is then called ratification." Corbin, Offer and Acceptance, and Some of the Resulting Legal Relations (I9I7) 26 Y ALE L. J. 169, I80.

100 Robinson v. Gould, II Cush. 55, 58 (Mass. I853).

${ }^{103}$ Bowman v. Hiller, I30 Mass. I53 (I88I).

${ }^{204}$ Coffelt v. Wise, 62 Ind. 451,458 (1878); (I923) 23 CoL. L. REv 72. 
makes the undertaking voidable only; and although the principal may refuse to avoid it, the surety may do so. Frequently fraud gives the principal an independent cause of action. If the princi$\mathrm{pal}$ is not a party to the creditor's suit against the surety who sets up compulsion or deception of the principal, the latter is deprived of his option to sue for damages occasioned by the fraud of the obligee, ${ }^{105}$ or to avoid the contract, which can be done only by returning whatever was received under it. ${ }^{106}$ By the common law, res inter alios acta did not recognize the surety as representative of or in privity with the principal, although in some jurisdictions the surety's right to rely upon the discharge of the principal is an exception to the general rule. ${ }^{107}$ The principal, if insolvent, is secure from the collection of any judgment obtained against him. He may retain the fruits of the contract. The surety whose financial responsibility caused the acceptance of the obligation is discharged. Thus recovery may be had from no one. However, the obligee has only himself to blame, for he imposed the duress, and should not be permitted to profit by his own wrong. ${ }^{108}$

Some courts have given expression to what may be classed as a modification of the first doctrine denying the plea of duress or fraud "unless the surety, at the time of executing the obiigation, is ignorant of the circumstances which render it voidable by the

${ }^{105}$ "A party when sued upon his obligation cannot avail himself of an independent cause of action existing in favor of his principal against the plaintiff as a defense or counterclaim. It is for the principal to determine what use he will make thereof and the surety has no control over him in this respect." Elliott v. Brady, I92 N. Y. 22I, 226, 85 N. E. 69, 7I (Ig08). Accord: Gillespie v. Torrance, 25 N. Y. 306 (I862). See Kirby v. Miller, 83 Ala. $48 \mathrm{r}, 3$ So. 700 ( 1888 ), holding that the sureties on a note for two principals could not set up fraud if the plea is joined in by only one of the principals.

${ }^{100}$ Henry v. Daley, 17 Hun 210, 211 (N. Y. I879).

${ }^{107}$ Gill v. Morris, II Heisk. 614, 620 (Tenn. 1872).

108 "If the principal could abide by the contract, and the surety repudiate it, the strange result would be produced, that the principal would retain the fruits of the contract, whilst the surety would avoid the performance of his obligation, on the ground of its invalidity, in direct opposition to the acts of his principal, admitting that the contract was valid. This would be to destroy the accessorial character of the contract of suretyship, without imposing on the surety the obligations of a principal debtor." Evans v. Keeland, 9 Ala. 42, 46 (1846). Accord: Walker v. Gilbert, 7 Sm. \& M. 456 (Miss. 1846). 
principal." 109 The result of denial of the defense to the surety unless he was ignorant of the duress works no hardship on any one. The contract, admitting the fact of fraud or duress, is voidable. If the surety had knowledge of the existence of the facts, it is fair to assume that he abandoned his possible defense. His right of indemnity continues so long as the principal has not avoided his undertaking, assuming the contract was not void. If the principal has avoided his liability, and the surety is acquainted with this fact, it is not inequitable to deny the latter reimbursement, since he entered into the contract with full knowledge of the consequences. To infer knowledge of the duress is not unfair to the gratuitous surety, whose intimate acquaintance with his principal's affairs is usually such as to give him knowledge of the facts surrounding the execution of the contract. Only the burden of proceeding is placed upon him by such a rule. Since the surety may waive his defense, his knowledge of the facts indicates that he has done so; and if he has waived it, the result is the affirmance of the voidable contract and there is no reason for relieving him. ${ }^{110}$

It has been suggested also that fraud on the principal is an injury to the surety as well, since the risk that he will be called

${ }^{103}$ Hazard v. Griswold, 2 I Fed. 178, 182 (C. C. R. I. I884). Accord: Fountain v. Bigham, 235 Pa. 35, 45, 84 At1. I3I, I35 (IgI2); Walton v. American Surety Co., $264 \mathrm{~Pa} 272,276,107$ Atl. 725,727 (I919). It was said in Graham v. Marks, 98 Ga. 67, 70, 25 S. E. 93r, 932 (r805) : "A surety upon such a paper is presumed to have knowledge of the circumstances surrounding his principal at the time he becomes his surety, and hence, in order to discharge himself from liability upon his contract, he must not only plead and prove, either the duress. of his principal by unlawful imprisonment, or duress by lawful imprisonment but for an illegal purpose, and, in the latter event, must prove not only the duress of the principal, but likewise his ignorance of such duress at the time he became surety; for, if he know of the imprisonment, it being legal, and not used for an illegal purpose, his risk is in no measure increased by any fact unknown to him beyond that of a surety under ordinary circumstances. If he incur a greater peril because of his becoming surety for one so circumstanced, he does it of his own free will, and there is no good reason in law or morals why he should not respond."

A note in (1920) 68 U. of PA. L. REv. 383, 386, after referring to the necessity for the surety to plead ignorance of the duress of the principal as held in Griffith v. Sitgreaves, $90 \mathrm{~Pa}$. I6I (1879), and followed in recent Pennsylvania cases, says: "The rule is absolutely without authority, because the cases referred to did not turn on the question of knowledge and none of them mention the fact that the surety had knowledge of the duress practiced on his principal, but it is reasonable and seems to work justice."

${ }^{10}$ Haney v. People, I2 Colo. 345, 350, 2I Pac. 39, 4 I (I889); Elliott v. Brady, I92 N. Y. 221, 226, 85 N. E. 69, 7 I (I908). 
upon to pay is increased. In such case, it has been urged that the surety should be released, not because of duress upon the principal, but for the reason that his risk has been increased.111 It is diffcult to follow the argument that there is a greater hazard when the principal does not repudiate his contract. The danger is that he may repudiate his obligation, in which case the surety will be discharged; if the principal fails to avoid it, the surety's responsibility is exactly what he expected it would be.

The preferable rule for a court to adopt where there has been fraud or duress by the obligee upon the principal, is to permit the surety to avail himself of this defense if the principal has rescinded. It is universally conceded that a repudiation by the principal of a voidable undertaking relieves the surety thereon. ${ }^{112}$ If the contract has not been rescinded, the surety should not be permitted to plead the defense of fraud or duress upon his principal. ${ }^{113}$ The principal has an equity which will relieve him, but it may be waived. An election for one having a right to waive an equitable defense can be made by no one else. ${ }^{114}$ Such a rule protects all parties. If the principal fails to set up the defense, he must reimburse the surety in the event the latter pays the obligee. If the principal avoids the contract, it is a matter subsequent like the discharge by the principal. ${ }^{115}$ The surety should

III (IgI8) 27 YALE L. J. 566.

w2 Hazard v. Irwin, 18 Pick. 95 (Mass. 1836) ; Macey, Henderson \& Co., Ltd. v. Heger, I95 Pa. I25, 45 Atl. 675 (1900); (rgr8) 31 HARv. L. Rev. 898, 899.

${ }^{123}$ See Note (1927) 21 ILL. L. REv. 637, 638; Scharnagel v. Furst, 215 Ala. 528, 530, II2 So. 102, I04 (I927). In Burwell v. First National Bank, I.59 N. E. 15, 17 (Ind. App. 1927), it is said: "In an action against the principal and sureties on a promissory note, fraud in inducing the execution of the note by the principal is a defense personal to the principal, and not to the sureties. and is available to the latter only when available to the principal. . . "

"When the principal and his sureties are sued jointly, the sureties cannot defend on a ground personal to the principal and which he had not pleaded. The principal in such a case has the right to waive the fraud and insist on the fulfillment of the contract. His suiety has no right to make that election for him."

in Brown v. Wright, 7 T. B. Mon. 396 (Ky. 1828), in the obiter of which it is intimated that if the principal refused to make his election because of collusion with the creditor, the surety might then make it.

${ }^{110}$ Chief Justice Shaw said in Hazard v. Irwin, 18 Pick. 95, 104 (Mass. 1836) : "Suppose it was discharged by payment, release or other matter subsequent, the defendants would not be estopped from showing it. Repudiating a contract, voidable on the ground of fraud, is matter subsequent precisely of the same character. The effect of the plea therefore is, not that the contract be- 
be relieved with the principal, since the latter's discharge wouldor should-prevent the recovery of indemnity by the surety. When the question is between the principal and obligee the defense should be regarded as personal; but when the question involves the right of a surety to plead fraud it should be considered within that large group of cases heretofore referred to, which courts dispose of on purely equitable considerations. ${ }^{118}$

If the surety alone is made defendant, of course the principal will not be precluded from pleading a defense by any judgment. In such event, Professor Williston suggests a bill in equity, with the surety as complainant, joining the principal and creditor as defendants, enjoining the creditor's action at law until it can be ascertained whether or not the principal has a defense against the creditor which will bar his action. In such suit, it may be determined whether the principal has the legal defense of fraud or duress, and if so, if he desires to waive it. ${ }^{117}$

The view suggested here as preferable received the sanction of the New York Court of Appeals in Ettlinger $v$. National Surety Co., ${ }^{118}$ in which the National Surety Company was evidently a surety as distinguished from a guarantor. ${ }^{119}$ The defendant's position as a compensated surety did not make it different from a gratuitous one. The contention that the defendant might set up fraud on the principal was denied because the contract was voidable at the option of the principal, who might return what he had received, and in a separate action recover damages for fraud imposed by the obligee, or he might ratify it. That the principal was or was not a party to the suit was of no concern. ${ }^{\mathbf{1 2 0}}$

Thus far we have been considering the surety in the technical

tween the plaintiff and defendants is void, on the ground of fraud, but that taking it to be valid and in full force, there is nothing due upon it from the defendants, as sureties, because the original contract between the plaintiff and Penman having been justifiably repudiated by the principal, there is nothing due from him." (1907).

${ }^{210}$ See note 73, supra; Royal v. Goss, I54 Ala. II7, I2I, 45 So. 23I, 232

IIt 2 WILLISTON, CONTRACTS (I920) § 1218.

${ }^{118} 221$ N. Y. 467, II7 N. E. 945 (I9I7).

${ }^{110}$ See Note (I918) I8 CoL. L. Rev. 158, 160, n. 12.

120 See discussions of the above case in Note (IgI8) 18 CoL. L. REv. I58;

(IgI8) 3I HaRv. L. Rev. 898; (IgI8) 27 YaIe L. J. 566. 
sense, as one who joins with the principal in a joint or a joint and several undertaking. No condition is implied in such case that there is a right against the principal; but obviously the result contended for, and which was reached in Ettlinger $v$. National Surety $C o$., would relieve any surety from liability whenever by repudiation the principal is no longer bound. This is not upon the theory that a principal who is legally liable is necessary to a surety, but for the reason that by the obligee's act justifying the principal's avoidance, it is equitable that all legal relations between the obligee and the surety should be terminated. Does the same reasoning apply in the case of a technical guarantor?

In a guaranty three persons in different positions are necessary. ${ }^{121}$ There may be an absolute and a conditional type of guaranty. ${ }^{122}$ Suppose that $A$ binds himself to $C$ to do some act if $B$ fails to do it; or secondly, suppose that $A$ promises $C$ to answer for the debt, default or miscarriage of $B .{ }^{123}$ The first case is based upon no condition, and bears all the marks of an absolute guaranty "by which the guarantor is bound immediately upon the principal failing to perform his contract without further condition to be performed." 124 An absolute guaranty to perform permits evidence of no conditions precedent. It seems an absolute guarantor is deprived of any defense which the principal might have, such as forgery of the principal's or an indorser's name. Such is the general language of the opinions $;^{125}$ but whether in case fraud or duress was imposed upon the principal a court would decide what the obiter indicates is impossible to prophesy. In Putnam v. Schuyler, ${ }^{126}$ the absolute guarantor was permitted to take ad-

${ }^{121}$ Arnold, Primary and Secondary Obligations (1925) 74 U. of PA. I.

REv. 36; First National Bank v. Drake, I85 lowa 879, I7I N. W. II5 (I9I9). 100 Beardsley v. Hawes, 7 I Conn. 39, 42, 40 Atl. 1043, 1044 (I898).

123 The illustrations in the text are suggested by the writer of the note in (I9I8) I8 COL. L. REv. I58.

${ }^{223}$ Cownie v. Dodd, I67 Iowa 627, 629, I49 N. W. 904, 905 (I914).

${ }^{125}$ Holm v. Jamieson, 173 Ill. 295, 50 N. E. 702 (1898); Veazie v. Willis, 6 Gray 90 (Mass. I856); Jones v. Thayer, I2 Gray 443 (Mass. 1859); Hungerford v. O'Brien, 37 Minn. 306,34 N. W. I6I (1887).

${ }^{109} 4 \mathrm{Hun}$ I66, I7I (N. Y. I875). Another case of this type is Swift v. Beers, 3 Denio 70 (N. Y. 1846). The defendant there guaranteed "payment of the above note at the time mentioned." The principal, a bank, was prohibited by statute from making such a note. The court said at $7 \mathrm{I}$ : "The guaranty partakes of the character of the principal contract. It was intended to reinforce 
vantage of fraud upon the principal since the defense was an inherent one and not merely personal.

But as to the second type of guaranty, where $A$ promises $C$ to answer for the debt, default or miscarriage of $B$, we find some cases involving alleged fraud upon the principal. The guaranty is conditional. Is the conditional guarantor to be considered the same as the absolute guarantor so far as such defenses are concerned? General language, such as the following, applicable to all guaranties, is frequently found, though the defense urged was neither duress nor fraud:

“. . . a guaranty of payment to one not a party to the instrument or claim guarantied, made upon a valuable consideration, or made under such circumstances as would work a damage to the party guarantied, is in effect a representation that the instrument or claim is perfectly legal and valid, as well as an undertaking to pay it in case of default of the person primarily liable, and concludes the guarantor from questioning the liability of the party on such instrument or claim." 127

It seems that courts might well distinguish between an absolute and conditional guaranty in determining what defenses are available. The contracts are so different that the liability might be affected by the character of the guaranty.

It is dubious whether the conclusion reached, if the obligee by fraud or duress has made the principal's contract void, would be the same in the case of an absolute guarantor as a surety. However, their undertakings are so dissimilar that the same reasoning has no necessary application. The surety is joined with the principal, for the same consideration, and is not bound upon an independent contract as is the guarantor. There is more reason for saying, therefore, that the absolute guarantor has, by his

and secure it-and is equally illegal." Similarly recovery against the absolute guarantor was denied in First National Bank v. Drake, 185 Iowa 879, 17I N. W. II5 (I9I9), but this was upon the authority of Auchampaugh v. Schmidt, 70 Iowa 642,27 N. W. 805 (I886), which was the case of a surety and not necessarily applicable.

12 Purdy v. Peters, 35 Barb. 239, 248 (N. Y. 186I). Following the above quotation the opinion admits that the guaranty may be given under such circumstances that the instrument guarantied and the guaranty must stand or fall together. 
absolute promise, waived any defenses growing out of the principal's contract. However, the absolute guarantor is entitled to recover indemnity from the principal. ${ }^{128}$ To permit recovery by the obligee against him presents the same difficulty heretofore suggested in allowing recovery against a surety under the same circumstances; if the guarantor may recover indemnity against the principal, the obligee is recovering from the principal indirectly when he could not do so directly. If reimbursement is denied the absolute guarantor, he is deprived of one of the most valuable rights given a surety or guarantor. It would seem logical, therefore, that the absolute guarantor be permitted, as is a surety, to set up fraud or duress on the principal in the event the principal has avoided his contract; if the principal has not denied his liability, then the absolute guarantor should be bound, which would entitle him to his right to recover indemnity against the principal.

\section{Defenses Available to the Surety or Guarantor on a Criminal BaIL Bond}

Possibly a majority of the courts allow the surety to plead fraud or duress by the obligee on his principal on any nonnegotiable undertaking. Should such jurisdictions permit a surety on a criminal bail bond to avail himself of the same defense? Undertakings for the defendant in a criminal action are in two forms: a recognizance, which is in the nature of a conditional judgment taken in open court, and proceeded upon by scire facias; and bail bonds, which may be taken out of court and in vacation. ${ }^{129}$ Because of a contravening public policy, a surety on a bail bond is never permitted to enforce reimbursement in the courts. ${ }^{130}$ The reasoning that it is inequitable to discharge the principal and bind the surety without preserving his right to recover indemnity, which may be urged in the case of an ordinary bond, is not applicable in the case of a surety on a bail bond.

128 Brandt, Suretyship and Guaranty (3d ed. I905) § 226.

120 People ex rel. Boenert v. Barrett, 202 Ill. 287, 67 N. E. 23 (I903); State v. Bradsher, I89 N. C. 40I, 405, I27 S. E. 349, 35I (1925); Cole v. Warner, 93 Tenn. I55, 23 S. W. IIo (I893); Swan v. U. S., 3 Wyo. I51, 9 Pac. 931 (1886).

${ }^{230}$ Herman v. Jeuchner, I5 Q. B. D. 561 (1885) ; U. S. v. Ryder, I ro U. S. 729, 4 Sup. Ct. 196 (1883). 
Furthermore any duress or fraud would not be by the obligee, the state, but by an agent acting outside the scope of his authority, and for which the obligee is not responsible. Nor is it necessary that a defendant in a criminal action be a party to the bond given for his appearance. Every argument for the release of the surety whose principal was the object of fraud or duress is absent in the case of a bail bond. No difference in reasoning can be seen whether suit be brought against one as a surety or as a guarantor on a criminal bail bond. ${ }^{131}$ If the surety be on a recognizanice, which is a conditional judgment, the futility of pleading duress of the principal is more apparent than had he signed a bail bond. A surety should not be able to resist a scire facias on a recognizance any more than collateral attack should be permitted on the judgment of any court. ${ }^{132}$

131 " . . . the limit to which any well-considered decision that has come under our observation has gone, is that if one is a surety, and no more, and enters into the contract in ignorance of the duress of the principal he may avail himself of the duress as a defense, because if the privilege is denied him he would be deprived of redress against his principal without fault on his part.

"But that reason cannot apply in favor of bail in a criminal case, because the law affords them no redress against their principal upon payment of their recognizance. The recognizance is a primary undertaking on their part. It is not necessary that the prisoner should be a party to it." Littleton v. State, 46 Ark. 4I3, $4 \mathrm{I} 8$ (1885). Accord: Spicer v. State, 9 Ga. 49 (I850); Huggins v. People, 39 IIl. 24I (1866).

${ }^{252}$ Peacock v. People, 83 Ill. 33I (1876) ; Oak v. Dustin, 79 Me. 23, 7 Atl. 815 (I887). State v. Brantley, 27 Ala. 44 (1855), seems contra, but was decided upon the authority of Watkins v. Baird, 6 Mass. 506 (I8ro), and Thompson v. Lockwood, I5 Johns. 256 (N. Y. 1818), neither of which, it is submitted, was a recognizance, and, whether correctly decided or not, are not authorities for a case arising as did State v. Brantley. The last sentence in the opinion in People v. Carroll, 44 Mich. 371,372 (1880), seems contrary to the statement in the text above, but the point decided was that the judgment of the justice was beyond his authority and could not be the foundation for a recognizance. See Ferry v. Burchard, 21 Conn. 597 (I852). 